\title{
Nation Divided: Building Identities through Bosnian History
}

\author{
ADNAN PECKOVIC \\ Lund University, Sweden
}

\begin{abstract}
This article focuses on the issue of promotion of ethnic divisions and producing collective narratives in primary schools in Bosnia and Herzegovina. Specifically, I will examine how the history textbooks (Bosnian, Croatian and Serbian) contribute to further dissolution of Bosnian society, how collective narratives are presented in the history textbooks and how the textbooks express the feeling of belonging to Bosnia and Herzegovina as a state. Findings show that the history curriculum (Bosnian, Croatian and Serbian) aims at supporting the 'us and them' politics through promoting group identity, through discrepancies in the history textbooks while describing important political events (the Islamisation of Bosnia and Herzegovina, the assassination of Duke Ferdinand, the start of WWI and WWII and especially the dissolution of Yugoslavia) through presenting members of the 'own' ethnicity as victims and 'others' as enemies. I argue that education in Bosnia and Herzegovina, especially in the field of history, supports further segregation of Bosnian society and that it needs quick reforms, so that young people from Bosnia and Herzegovina can participate in democratic and pluralistic society.
\end{abstract}

\section{Keywords}

nationalism, collective narratives, educational reforms, primary schools, history textbooks, segregation

\section{Introduction}

The war in Bosnia and Herzegovina from 1992 - 1995 has left many unsolved issues, even 18 years since it ended. One of those issues is segregated education. At this time there are three different school curriculums that are implemented in Bosnian schools. Society in Bosnia and Herzegovina is deeply divided between three sides that were in conflict during the war, Bosniaks (mostly Islamic), Croats (Catholic) and Serbs (Orthodox). Bosnia and Herzegovina today is divided into two entities (the Federation of Bosnia, which is mainly Bosniak and Croat parts, and the Serb Republic -the part of Bosnia where Serbs are in the majority). The Federation of Bosnia is then divided into 10 cantons, some with a Croat majority population and others with a Bosniak majority population. Each side is implementing their own school plan and programme on the territory where they are in the majority. It is important to mention that the cantons and the entity of the Serb Republic are in charge of the education system and the state has almost no influence over it.

The most common and vivid example of segregation in Bosnian education is the so called 'Two schools under one roof'. Students are taught in the same building, but are divided according to their ethnicity and are taught 
according to different curricula. Students also enter their schools through separate entrances and the schools have separate administrations.

Speaking of the International Community's (IC) role in education reforms in post-war Bosnia and Herzegovina it is important to mention that, although the Dayton Peace Agreement (DPA) Accords have covered the education sector in Annex 6, still education reforms were not assigned to any specific international organisation or institution to implement (Perry 2003: 42). Perry argues that four factors influenced the education reforms in Bosnia and Herzegovina:

- It was seen as a domestic issue

- There was no strong organisation to lobby for inclusion of education

- The short-term mind set of the international community during drafting the DPA

- Parties that have signed the DPA were not eager to hand over education reforms to foreigners, because politicians and citizens wanted to establish 'their own' education. (Perry 2003: 42-43)

Even though there was no official mandate for education reforms in Bosnia and Herzegovina there were high level efforts to pursue them. One of these is the 1997 Peace Implementation Council (PIC) meeting in Bonn where competent authorities were called to work together to ensure that all persons are educated according to their needs and in a manner which also contributes to tolerance and stability within a multi-ethnic Bosnia and Herzegovina, and to develop without delay an education programme consistent with these principles, in co-operation with the High Representative, UNESCO, the Council of Europe, the European Commission, the OSCE, UNICEF, the World Bank and other relevant organisations (Perry 2003: 47).

Finally, under the influence of OHR, OSCE, UNESCO, UNICEF and other international organisations, in 2002 the ministries of education from all the governing levels signed the statement that says: We, the ministries of education, will ensure that all children have access to quality education in integrated multicultural schools, education that has been freed from political, religious, cultural and other prejudices and discrimination and which takes into consideration the rights of all children (Husremović, Powell, Šišić and Dolić 2007: 16).

Still, education remains segregated.

This article will contribute to understanding of the issue of nationalism and segregation in Bosnian schools and its effects on current relationships amongst children of different ethnic and religious backgrounds in the education system in contemporary Bosnia and Herzegovina. 
The aim of this article is to explore values and concepts presented in the history textbooks and how different historical events are described in different history textbooks. The content analysis of history textbooks will provide me and the readers with information about if and in what way the history textbooks promote ethnic divisions amongst students in primary schools and in that way possibly contribute to educational reforms in Bosnia and Herzegovina.

The history text books analysed in this article serve to showcase how the educational system in contemporary Bosnia and Herzegovina is used to construct collective narratives amongst students in primary schools. They will also give us insight into how different ethnic groups perceive certain historical events that are generally seen with different eyes from the points of view of different ethnic groups. This is not in fact a new phenomenon in the history of Bosnia Herzegovina. In communistic Yugoslavia issues such as conflicts amongst ethnicities were 'swept under the carpet' and therefore not dealt with constructively, helping to foster nationalistic parties in the end of the 80s which brought these issues to the surface and produce a new conflict. These different points of view can be used to deepen the conflict amongst ethnicities in Bosnia and Herzegovina. Education, especially History as a school subject, plays a very important role in constructing these disintegrating or integrating narratives. As Radušić (2009: 1) has said education can be a disintegrating or an integrating factor in divided societies. In this sense education cannot be neglected as a peace forming factor and a security issue in Bosnia and Herzegovina.

\section{Theoretical perspectives}

\section{Nationalism}

Anthony D. Smith defines nationalism as an ideological movement for attaining and maintaining autonomy, unity and identity on behalf of a population deemed by some of its members to constitute an actual or potential 'nation' (Smith 1991: 73). Ernest Gellner defines nationalism as primarily a political principle, which holds that the political and the national unit should be congruent. (Gellner 2009: 73). Gellner also claims that nationalism is indeed an effect of industrial social organisation; it is not the only effect of the imposition of this new social form, and hence it is necessary to disentangle it from those other developments (Gellner 2009: 40). Especially important for this article is Gellner's argument that nationalism is a theory of political legitimacy, which requires that ethnic boundaries should not cut across political ones (Gellner 2009: 1). Eric Hobsbawm argues that the basis of 'nationalisms' of all kinds was the same: the readiness of people to identify themselves emotionally with 'their' nation' and to be politically mobilised as 
Czechs, Germans, Italians or whatever, a readiness which could be politically exploited (Hobsbawm 1989: 143).

\section{Nationalism and Education}

Mass public education system is an important tool for creating and maintaining mass ideologies such as nationalism. Smith argues that national identities also fulfil more intimate, internal functions for individuals in communities. The most obvious is the socialisation of the members as 'nationals and 'citizens'. Today this is achieved through compulsory, standardised, public mass education systems, through which state authorities hope to inculcate national devotion and a distinctive, homogeneous culture, an activity that most regimes pursue with considerable energy under the influence of nationalist ideals of cultural authenticity and unity (Smith 1991:16). Smith also claims that the task of ensuring a common public, mass culture has been handed over to the agencies of popular socialisation, notably the public system of education and the mass media (Smith 1991: 11). Especially affected are school subjects such as history where historical facts are often manipulated or even invented. Hobsbawm argues that history is the raw material for nationalist or ethnic fundamentalist ideologies as poppies are the raw material for heroin addiction (Hobsbawm 1997: chapter 1). He also argues that this is an essential element of these ideologies. If there is no suitable past, it can always be invented (Hobsbawm 1997: chapter 1). Apple argues that a curriculum is never simply a neutral assemblage of knowledge, somehow appearing in the texts and classrooms of a nation. It is always someone's selection or vision of legitimate knowledge (Apple 1993: 222). Usually the dominant group decides what legitimate knowledge is. Apple argues that there is a 'new hegemonic block' which is made of three different groups: Neo-liberalists, who want education policy to be based around economy, neo-conservatives whose main agenda is the cultural 'restoration' and the third one is the Christian fundamentalist group who want to return the Biblical tradition as the basis of knowledge and the fourth group as he says is made of the professional and managerial new middle class (Apple 2001: 2-3). In terms of multi-cultural education Apple argues that the dominant groups have taken mostly moderate and safe forms of multiculturalism and put them into curricula, so now in text books we have something that Apple has called 'mentioning' so the contribution of 'the other' is only mentioned (Apple 2001: 2-3). This way their status as 'the other' is guaranteed. He also argues that speaking of text books the political right had to compromise in order to maintain their leadership so they had to have some content about women, unions, and racial dynamics in their history (Apple 2001: 14).

Speaking of power sharing and relationships among different groups in multi ethnic societies Sidanius and Petrocik say that there are theories of intergroup 
relations that are referred to as group dominance models which support the thesis that societies tend to be organised as group based hierarchies, where dominant groups enjoy power, prestige and privilege while the subordinate social groups are poor (Sidanius and Petrocik 2000: 6). Dominant groups usually achieve hegemony through discursive practice and rarely through force. They achieve it through pushing towards particular identifications especially in post-colonial societies while promoting internal plurality were the state constantly seeks nation building projects (Durrani and Dunne 2004: 218).

\section{Ethnicity and Nation}

It is important at this stage to distinguish between ethnicity and nation. According to Horowitz ethnicity is a sense of collective belonging which could be based on common decent, language, history, culture, race and religion or some combination of these (Horowitz 1985 in Varshney 2009: 277). According to Varshney a nation is a group with territorial and political home (Varshney 2009: 277). In their article 'Europeanization in the 'other' Europe: writing the nation into 'Europe' education in Slovakia and Estonia', Deborah Michaels and Doyle Stevick mention two different concepts of nation: the ethno-cultural nation and civic nation (Michaels and Stevick 2009: 228). The ethno cultural nation is based on belonging in terms of particularistic ethnic and cultural attributes that are depicted as objective and organic rather than socially constructed. It is based on tribal origins and myths. In the civic nation concept there are no inherited threads of behaviour, but a common core of political values (Michaels and Stevick 2009: 228). Being a member of a 'tribe' or in other words belonging to one ethnicity has been of great importance for Bosnian people for centuries. And still today it shapes the politics of Bosnia. One could argue that the identity question in Bosnia has never been solved, from the Ottoman Empire until current times.

\section{Politics in Contemporary Bosnia and Herzegovina}

The political system as it is organised at the moment in Bosnia and Herzegovina is ethnically coloured and all three main ethnicities pursue efforts to maintain their positions. There is a small number of citizens of Bosnia that do not feel they belong to any of the main ethnicities, although they share the same background, but still call themselves Bosnians (in terms of belonging to the Bosnian state, and not only to one ethnicity). The number of these people cannot be determined at the moment, but it is generally considered that it is $2-3 \%$ of the population. Michaels and Stevick used the example of Slovakia and Estonia, who had a similar destiny to Bosnia and Herzegovina (besides from the war itself) (Michaels and Stevick 2009: 229). The key similarity between these three countries (Bosnia and Herzegovina, Slovakia and Estonia) is that they all had a very short amount of time of 
sovereignty and had over 40 years of communistic rule. They have described how the civic education textbooks promote Europe as a model for democratisation and not only Europe, but also the United States and the United Nations. The American Revolution and American presidents George Washington, Thomas Jefferson, and Abraham Lincoln replaced earlier images of socialist heroes such as Marx and Lenin (Jaksicsová 1995: 23, Kuírek et al. 1997: 19, Vavrová 1997: 211 in Michaels and Stevick 2009: 231).

Gavriel Salomon, professor at the University of Haifa in Israel, relying on Buner (1990) gives the following definition of collective narratives:

Collective narratives are the comprehensive collection of stories, beliefs, aspirations, histories, and current explanations that a group holds about itself and about its surroundings. Collective narratives are social constructions that coherently interrelate a sequence of historical and current events; they are accounts of a community's collective experiences, embodied in its belief system and represent the collective's symbolically constructed shared identity (Bruner 1990 in Salomon, 2004: 274).

If a country has three different narratives about historical events then it could become a problem. That is my main motivation to examine history textbooks and to discover if and in what way the same historical events are portrayed differently in different ethnic curriculums. Salomon argues that the ultimate goal of coexistence education ought to be the legitimisation of the other side's collective narrative and its implications (Salomon 2004: 278). This argument also comprises with Radušić's (2009) claim not to hold on to exclusive truths when teaching history, but to provide students with other points of view (Radušić 2009: 7).

Although other research has discussed the topic of segregated education in Bosnia and the school "National Group of Subjects" none of them have touched the issue of the importance of certain historical events for ethnic relations in Bosnia today and how it influences education today.

Questions that will help me answer the main question of this article are:

- How do the narratives in history textbooks express belonging of all three main ethnic groups to Bosnia and Herzegovina?

- How do the history textbooks present people of their own and other ethnic background?

How are new collective narratives constructed through history textbooks?

\section{Methodology and the focus of the research}

I will focus on analysing primary school history textbooks that are used in Bosnia and Herzegovina from the $5^{\text {th }}$ to $9^{\text {th }}$ grade. The aim of the content analysis of history textbooks is to examine eventual discrepancies in the points of view on several historical events or how they relate to each other. In 
analysing the history textbooks I will examine if they promote belonging to the Bosnian state, how they present "the others" and "own ethnic group", whether they serve to construct collective narratives and how they are presented. I will also examine the effects of possible discrepancies on ethnic relationships in Bosnia. This will be implemented through qualitative analysis of History textbooks by comparing the data and giving commentary to each segment of research.

The historical events I will examine are:

- The Islamisation of Bosnia and Herzegovina

- The beginning of World War I and the assassination of Arch-duke Franz Ferdinand

- World War II

- Dissolution of Yugoslavia

I believe that all four historical events are a source of conflict between the three main ethnic groups in Bosnia and Herzegovina and will argue that the teaching methods when these events are taught to children should be reexamined. All four of them are covered with mythos and are fuel to ethnic tensions in Bosnia and Herzegovina. During my discussions on the topics of discrepancies in the content of history textbooks with history teachers and reading through the history textbooks I have decided to focus this research on these four historical events mentioned above.

The textbooks that I have chosen for content analysis are textbooks that are currently used in Bosnian primary schools from $5^{\text {th }}-9^{\text {th }}$ grade and these are good representation of what is thought in terms of history in Bosnia. However, history textbooks are only part of the story of building collective narratives and historical mythos in Bosnia. Much more extensive research would include also other subjects from the "national group of subjects" (Geography, History, Language and Religious Education). However I believe that history textbook analysis can provide insight into whether the Bosnian education system is a designating or integrating factor in Bosnian society. Since educational system is in the obligation of political power we can also gain insight into political aims and goals and what the actual political agenda is in currant Bosnia.

In total I will analyse seven textbooks:

Bosnian curriculum: society from the $5^{\text {th }}$ grade of primary school, history textbook for the $7^{\text {th }}, 8^{\text {th }}$ and the $9^{\text {th }}$ grades of primary school 
Serbian curriculum: society from the $5^{\text {th }}$ grade of primary school, history textbook for the $9^{\text {th }}$ grade

Croatian curriculum: On the path of our past (history textbook for the $6^{\text {th }}$ grade)

I have chosen these specific textbooks for my content analysis because they discuss historical the events I have mentioned above.

\section{Results/Findings: Content analysis of the textbooks}

I have decided to use seven history text books. Four of them are from the Bosnian curriculum; two are from the Serbian curriculum and one from the Croatian curriculum. All seven are dealing with topics I wished to examine. After some informal conversations with history teachers I was advised to use these seven. I will examine the values and concepts presented in the textbooks.

\section{Ottoman Empire and Islamisation of Bosnia and Herzegovina}

The issue of Islam coming to Bosnia and Herzegovina is one of the historical events that is a source for tension amongst ethnic groups. In public discourse Bosnian Muslims today are 'Serbs who accepted Islam under the pressure of ottomans and therefore traitors'. This is something you can hear a lot and read on a lot on social networks.

In the society textbook for the $5^{\text {th }}$ grade (Serbian curriculum) the fall of Bosnian Kingdom under the Ottoman Empire was described in one paragraph. The author gave an introduction where they described the fall of Serbia under the Ottoman Empire describing the Kosovo battle (28.06.1389) as crucial battle for Serbia. The authors argue that Bosnia has fallen very quickly under the Ottomans and that the Ottomans have captured and killed Bosnian King Stjepan Tomšević. ${ }^{1}$ Further on the authors describe the life of people in Bosnia during the Ottoman Empire. Here they say that people did not have any rights, but only many obligations to the Empire, such as different taxes. ${ }^{2}$ Authors state that the worst of the obligations was what Ottomans called 'blood taxes' (I have not been able to find more appropriate translation) which meant that the Ottomans have taken healthy male children and prepared them to be Ottoman soldiers. Another chapter in this book discusses the people's resistance against the Ottoman Empire in Bosnia and Serbia. Authors argue that the hard life of Christians under Ottoman rule led

\footnotetext{
1 Pašalić, Stanojlović, Vukadin (2011) Poznavanje društva za 5 razred osnovne škole, Zavod za udzbenike i nastavna sredstva Istočno Sarajevo, p. 84 (Pašalić, Stanojlović, Vukadin (2011) Knowing your society for the 5th grade of primary school, Department for textbooks and learning material East Sarajevo).

2 Pašalić, Stanojlović, Vukadin (2011) Poznavanje društva za 5 razred osnovne škole, Zavod za udzbenike i nastavna sredstva Istočno Sarajevo, p. 85-87 (Pašalić, Stanojlović, Vukadin (2011) Knowing your society for the 5th grade of primary school, Department for textbooks and learning material East Sarajevo).
} 
to organisation of resistance and write that the first resistance movements against Ottomans were in Serbia (in 1804 and 1815). Serbian resistance has served as a model for the resistance in Bosnia. Biggest resistance battle in Bosnia happened in 1875 which has lasted for three years. It is notable that all the resistance leaders mentioned in this textbook were Bosnian Serbs. This textbook dedicates four pages to this event.

In the Bosnian society textbook (Bosnian curriculum) for the $5^{\text {th }}$ grade the fall of Bosnia under the Ottoman Empire was also only briefly described, but it is notable that the language used is different. Authors stated that it was in the $15^{\text {th }}$ century, when the Ottomans conquered Bosnia that medieval Bosnia fell apart. They said that Bosnia was completely conquered in 1463 and that Bosnia inside the Ottoman Empire had a special status in terms of administration. During the Ottoman Empire cities in Bosnia started to develop, so Sarajevo (capital of Bosnia and Herzegovina) became one of the biggest cities in the European part of the Ottoman Empire ${ }^{3}$.

In the history textbook for the $6^{\text {th }}$ grade (Croatian curriculum) it is written that Bosnia as an administrative unit inside the Ottoman Empire was formed in 15804. The authors say that the crisis that was present in whole Ottoman Empire was also present in Bosnia at that time. Accordingly the state had the need to increase its income so it gave land to local land owners who collected taxes for the state. The authors also argue that the life of Christians at that stage was very difficult, but still, the number of Christians has increased in the $18^{\text {th }}$ century. There were also other forms of discrimination towards Christians; they were not allowed to wear green (a traditional Islamic colour) and humble behaviour toward Muslims was demanded of them. The authors argue that with the Ottoman Empire came Islam. Islam has left the deepest roots in Bosnia, because the Church organisation was very weak at that stage. Everyone who converted to Islam could reach high functions in society and the economic situation of Christians in the villages was much worse that the once of the Muslims, Christians had to pay taxes, so there were many reasons to convert to Islam.

According to the $7^{\text {th }}$ grade textbook (Bosnian curriculum) Bosnia fell under the Ottoman Empire in 1463, but the whole Bosnian kingdom was not

\footnotetext{
3 Idrizović (2009) Društvo - Udzbenik za 5 razred osnovne škole, Federalno Ministarstvo za Obrazovanja i Nauke, p.29 (Idrizović (2009) Society textbook for the 5th grade of primary school, Federal Ministry for Education and Science, p.29).

4 Brdal, Madunić \& Lovrinović (2010) Tragom prošlosti - Udžbenik za 6-ti razred osnovne škole, Školska knjiga Zagreb i Školska naklada Mostar, p.167.

(Brdal, Madunić \& Lovrinović (2010), On the path of our history-History textbook for the 6th grade of primary school, School Book d.d Zagreb i School edition Mostar, p.167).
} 
occupied until 15925. Speaking about taxes, the authors argue that both (Muslims and Christians) had to pay almost the same taxes. The difference was that Muslims could take high social political positions and Christians could not. Muslims were obligated to go into the army and Christians were not. The authors claim that in Bosnia all religions enjoyed a great amount of freedom. As an example of that they give the charter of Mehmed II Fatih (Ottoman Emperor) from 1463 which granted freedom to Catholic priests to promote their religion.

\section{The beginning of the WWI and the assassination of the Archduke Franz Ferdinand}

On the 28.06.1914 Gavrilo Princip assassinated Archduke Franz Ferdinand and his wife. This event is considered as the beginning of WWI.

Textbooks from the Serbian curriculum say that Gavrilo Princip, member of an organization called 'Young Bosnia' (Mlada Bosna) assassinated Arch-duke Franz Ferdinand and his wife in Sarajevo (the Bosnian capital) on June 28, 1914 and that the Austro-Hungarian Empire used this event as an excuse to attack Serbia. Austro-Hungarian political leadership gives an ultimatum to Serbia to let Austro-Hungarian police implement the investigation in Serbia, which Serbia refuses. ${ }^{6}$ The assassins were quickly arrested and brought to trial. Three of Gavrilo's associates were hanged but since he was a minor he could not receive the death penalty. He was sentenced to 20 years in prison and died there, because he was tortured with hunger and beatings. After the assassination Austro-Hungarian authorities began a campaign against Bosnian Serbs. They started closing their shops, arresting Serb intellectuals, even Ivo Andrić. During this time many Serb intellectuals were accused of working against the Austro-Hungarian Monarchy and brought to trial and sentenced ${ }^{7}$.

In history textbooks from the Bosnian curriculum it is stated that the spark of war was lit by the assassination of Archduke Franz Ferdinand and his wife. That was done by Serb nationalists in Sarajevo on June 28, 1914. It is said that these nationalists were members of an organisation called 'Young Bosnia' (Mlada Bosna) which was supported by Serbia. Arch-duke Franz Ferdinand came to Sarajevo to observe a military manoeuvre. In history textbooks from

\footnotetext{
5 Dervišagić, Hadžiabdić, Mulić \&Mehić (2010) Historija-Udžbenik za 7 razred osnovne škole, Bosanska knjiga, p. 125 (Dervišagić, Hadžiabdić, Mulić \&Mehić (2010), history textbook for the 7th grade of primary schools, p. 125).

6 Pejić, Tešić \& Gavrić (2011) Istorija za 9 razred osnovne škole, Zavod za Udžbenike i nastavna sredstva Istočno Sarajevo, p. 55-56 (Pejić, Tešić \& Gavrić (2011), History textbook for the 9th grade of primary school, Department for textbooks and learning material East Sarajevo, p. 55-56).

7 Pejić, Tešić \& Gavrić (2011) Istorija za 9 razred osnovne škole, Zavod za Udžbenike i nastavna sredstva Istočno Sarajevo, p. 68-70 (Pejić, Tešić \& Gavrić (2011), History textbook for the 9th grade of primary school, Department for textbooks and learning material East Sarajevo, p. 68-70).
} 
the Bosnian curriculum the events which happened after the assassination were also described. After the assassination there was a big campaign against Serbs in Bosnia. Most Serbian property was confiscated and Serbian run stores were closed. After these events, representatives of all three ethnic groups visited the Austro-Hungarian authorities in Bosnia and lobbied for the campaign to stop. Even the Catholic and Islamic religious institutions lobbied for the campaign to stop. Austro-Hungarian authorities, on the 06. 02.1910, suspended the Bosnian assembly ${ }^{8}$.

\section{World War II}

Serbian textbooks say that in April 1941 the Yugoslav Kingdom was attacked by Germans: The Germans bombed Belgrade (the capital of Serbia) and between 2,300 and 4,000 citizens died. The Yugoslav Government retreated to Uzice (City in south - west Serbia). Muslim and Croat representatives retreated from the Yugoslav Government. King Petar left Yugoslav ground and escaped to London. That was the end of the first Yugoslavia. Hitler and his allies (Italians and Hungarians) divided Yugoslavia amongst each other ${ }^{9}$. Bosnia and Herzegovina was annexed to the Independent Croatian State which was under German rule. As German troops entered Zagreb (the capital of Croatia) people greeted them with happiness and threw flowers at German soldiers ${ }^{10}$. The aim was to extradite one third of the Serbs, one third should be converted to Catholicism and one third should be executed. Jews and Roma should also be eliminated quickly. In order to be supported by Muslim inhabitants of Bosnia they argued that Bosnian Muslims were actually Croats (Croatian flowers they said). Croatian army (Ustashe) started with mass executions of Serbs, Roma and Jews in concentration camps. In Jasenovac concentration camp alone (a small city in north Croatia) 700000 Serbs, Jews, Roma and antifascists were executed ${ }^{11}$. In Bosnia and Herzegovina a new Muslim militia was formed ${ }^{12}$. Serbian textbooks described the forming of the Independent State of Croatia as act of betrayal. As resistance to Germany and its allies Partisan Communist and Chetnic (Serbian military under the

\footnotetext{
8 Ganibegović, Durmišević \& Pelešić (2001) Historija-Povijest za 8 razred osnovne škole, Svjetlost Sarajevo, p.15-16 (Ganibegović, Durmišević \& Pelešić (2001) history textbook for the 8th grade of primary school, Svjetlost Sarajevo, p.15-16.

9 Pejić, Tešić \& Gavrić (2011) Istorija za 9 razred osnovne škole, Zavod za Udžbenike i nastavna sredstva Istočno Sarajevo, p. 102-105 (Pejić, Tešić \& Gavrić (2011) history textbook for the 9th grade of primary school, Department for textbooks and learning material East Sarajevo, p. 124-125).

10 Pejić, Tešić \& Gavrić (2011) Istorija za 9 razred osnovne škole, Zavod za Udžbenike i nastavna sredstva Istočno Sarajevo, p. 102-105 (Pejić, Tešić \& Gavrić (2011) history textbook for the 9th grade of primary school, Department for textbooks and learning material East Sarajevo, p. 127).

11 Pejić, Tešić \& Gavrić (2011) Istorija za 9 razred osnovne škole, Zavod za Udžbenike i nastavna sredstva Istočno Sarajevo, p. 102-105 (Pejić, Tešić \& Gavrić (2011) history textbook for the 9th grade of primary school, Department for textbooks and learning material East Sarajevo, p. 136).

12 Pejić, Tešić \& Gavrić (2011) Istorija za 9 razred osnovne škole, Zavod za Udžbenike i nastavna sredstva Istočno Sarajevo, p. 102-105 (Pejić, Tešić \& Gavrić (2011) history textbook for the 9th grade of primary school, Department for textbooks and learning material East Sarajevo, p. 131).
} 
command of Dragoljub Mihajlović) movements were formed. Both these movements express the wish to resist the occupation, Chetnics and the Government in exile also resisted the Partisans and its Communist leadership. In Belgrade in 1941 the Peoples Liberation Movement was formed and Josip Broz Tito was its leader. Now, we have two movements of resistance: the Chetnic movement (whose goal was to establish a new Serb state and return of the pre-war political system) and the Partisans (with the aim to establish a new Yugoslav state which would be a federal state and a socialist republic).

According to Bosnian textbooks Croatian ideology corresponded with German ideology. Independent Croatian State belong exclusively to Croats. Already in the formation of first days of the Independent Croatian State mass killings of Serbs, Roma and Jews had started, and in addition Muslim sand Croats that did not support the regime were executed. A small number of Bosnian Muslims joined the Croatian regime. Most Muslims, including the Islamic religious institution, condemned the mass killings. Several protest charters were published against mass killings. Some Bosnian Muslims, who did not accept the Croatian regime, lobbied for Bosnian autonomy under German protection and decided to protect them ${ }^{13}$. Most of them joined the Partisans at a later date. Together with the mass killing done by the Croatian regimes the Chetnics started mass killings of Bosnians, Muslims and Croats. Their goal was to renew Yugoslavia and establish 'homogenous Serbia' in it. Following that aim Chetnics had on several occasions executed mass killings of Bosnian Muslims in eastern Bosnia. Chetnics viewed the Partisans as a bigger threat than the Germans, so they started a war against Partisans too ${ }^{14}$. The Partisans' aim was to bring all antifascists together no matter what religious, national or other background they have. In order to defiantly defeat Partisans Hitler ordered a huge offensive against Tito's army. The German army, together with Croatian forces, Italians and Chetnics attacked Partisans in eastern Bosnia, but Tito managed to escape.

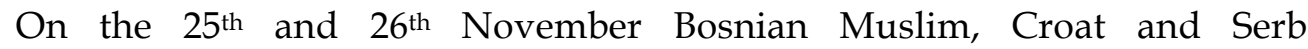
representatives in the Communist Party decided to renew the Bosnian state and include it the new Yugoslavia.

Croatian textbooks state that the Croatian Regime in many senses imitated the German regime. They opened concentration camps for Serbs, Jews and Roma. Not only Serbs, Jews and Roma were taken to concentration camps,

13 Ganibegović, Durmišević \& Pelešić (2001) Historija-Povijest za 8 razred osnovne škole, Svjetlost Sarajevo, p.85-86 (Ganibegović, Durmišević \& Pelešić (2001) history textbook for the 8th grade of primary school, Svjetlost Sarajevo, p.85-86.

14 Ganibegović, Durmišević \& Pelešić (2001) Historija-Povijest za 8 razred osnovne škole, Svjetlost Sarajevo, p.85 (Ganibegović, Durmišević \& Pelešić (2001) history textbook for the 8th grade of primary school, Svjetlost Sarajevo, p.85. 
but also those considered to be disloyal Croats. The Biggest concentration camp was Jasenovac where 48,000 Serbs, Jews and Roma were executed (Matkovic et al 2006).

\section{Dissolution of Yugoslavia}

According to Bosnian textbooks in Socialist Yugoslavia there was a great economic crisis. Inflation reached $80 \%$, Yugoslavia was so much in debt that it could not even pay the interest. Together with economic crises nationalism was also on the rise. Slovenia wanted more independence, Albanians wanted Kosovo to become a republic and Serbian politicians argued that Kosovo (part of southern Serbia with an Albanian majority) and Vojvodina (part of southern Serbia with a Hungarian majority) was Serbian territory ${ }^{15}$. In 1987 Slobodan Milošević became a leader of Serbian Communists. His aim was to make a centralised Yugoslavia with Serbian power which meant that all the main decisions would be made in Belgrade. During the 14th Assembly of the Communist Party, because of tensions with Serbian Communists, the Croatian, Bosnian and Slovenian Communists left the assembly. In the next period the formation and legalisation of other political parties began ${ }^{16}$. Most of them were ethnically and religiously coloured. The strongest parties in Bosnia were the Party of Democratic Action (Bosnian), Serbian Democratic Party (Serbian) and Croatian Democratic Union (Croatian). After Slovenia and Croatia declared independence the Bosnian assembly declared Bosnian independence, too. Serbian representatives left the assembly and declared the Serbian Republic of Bosnia and Herzegovina on one part of Bosnian territory. In the meantime, respecting the obligations towards the European Community, the legitimate Bosnian Government declared a referendum about Bosnian independence. The majority of citizens voted for an independent Bosnian state.

According to the Serbian textbook Serbia suffered a great loss through the Yugoslav Constitution of 1974, Kosovo (part of southern Serbia with an Albanian majority) and Vojvodina (part of southern Serbia with a Hungarian majority) received a great amount of autonomy. They had the entire political organ that one state had. Statehood of each republic in Yugoslavia has slowed down normal functioning of Yugoslav institutions. Serbian people on Kosovo were in a very difficult position since the Albanian separatists argued for Kosovo to unite with Albania. In all the Yugoslav republics new political parties were formed, and they were mostly nationalistic political parties. The Croatian nationalist party, Croatian Democratic Union, has won in the 1991

15 Šabotić 6 Čehajić (2012) Historija - 9 razred osnovne škole, NAM Tuzla, p. 179 (Šabotić 6 Čehajić (2012) history textbook for the 9th grade of primary school, NAM Tzla, p. 179).

16 Šabotić 6 Čehajić (2012) Historija - 9 razred osnovne škole, NAM Tuzla, p. 180 (Šabotić 6 Čehajić (2012) history textbook for the 9th grade of primary school, NAM Tzla, p. 180). 
elections in Croatia and they have decided that Serbs are not a constitutive nation in Croatia any more. Serbian assembly has after that pronounced Serbian Republic inside Croatia. In Bosnia Serbian and Croatian political parties contributed to the breakdown of Yugoslavia. In the year 1991 Serbian politicians implemented a referendum amongst Serbs about staying in Yugoslavia. The majority of Serbs wished to stay in Yugoslavia. On the basis of these results Serb politicians declared a Serbian Republic in Bosnia and Herzegovina, which would later be called Republic of Serpska. Bosnian and Croatian politicians have without the consent of Serbian politicians declared Bosnian independence and organised a referendum where the relative majority of Bosnians and Croats voted for an independent Bosnia. The international community recognised Bosnia as an independent state which led to a war between Bosnian Muslims, Serbs and Croats ${ }^{17}$.

\section{Concluding discussion}

In the concluding discussion I will give examples of how the history textbooks focus on only one ethnic group, the neighbouring countries and how they promote conflict amongst three different ethnicities in Bosnia and Herzegovina.

a) Focus on one (their own) ethnic group and neighbouring countries

In the society textbook for 5th grade the authors describe the fall of the Bosnian kingdom in one paragraph, but focus on the fall of Serbia under Ottoman rule and describe the Kosovo battle as the main battle for Serbia. The authors describe the lives of Christians under Ottoman rule and argue that the first acts of resistance against the Ottomans took place in Serbia. All the resistance leaders mentioned in the society textbook for 5th grade are Serbs. Authors in the Bosnian curriculum claim that Bosnia, as part of Ottoman Empire, had a special status. Authors of the Bosnian curriculum claim that during Ottoman rule cities in Bosnia started to develop. Authors in the Bosnian curriculum claim that life of Christians in Bosnia was difficult, but their number increased in the 18th century. Authors in the Bosnian curriculum claim that Christians in the villages were poorer then the Muslins and that was an important reason for Christians to convert to Islam. The focus on one nation was also clear when the textbooks describe the start of WWI. The Serbian textbooks argue that the assassination of Archduke Ferdinand was only an excuse to attack Serbia. In the Bosnian curriculum textbooks it is stated that, after the assassination, Austro-Hungarian authorities started a campaign against Bosnian Serbs, where most of their property was

17 Pejić, Tešić \& Gavrić (2011) Istorija za 9 razred osnovne škole, Zavod za Udžbenike i nastavna sredstva Istočno Sarajevo, p. 192-195 (Pejić, Tešić \& Gavrić (2011), history textbook for the 9th grade of primary school, Department for textbooks and learning material East Sarajevo, p. 192-195). 
confiscated. In the Bosnian curriculum textbooks it is also stated that representatives of all three ethnic groups lobbied to stop the campaign against Serbs. Serbian curriculum textbooks argue that Serbs have suffered the greatest loss and that Serbs in Kosovo were in a difficult position, because Kosovo Albanian separatists wanted to unite with Albania. These examples show us the promotion of one Serb nation on both sides of the border and promotion of Serbia as their homeland. For nationalists 'homeland' is crucial and it is usually argued that 'it is ours for centuries and generations'. Smith argues that it is, and must be, the 'historic' land, the 'homeland', the 'cradle' of our people, even where, as with the Turks, it is not the land of ultimate origin (Smith 1991: 9). We can also recognise a political effort to put all Serbs under one political umbrella where a certain set of values are promoted. As Smith argues "Finally, the legal equality of members of a political community in its demarcated homeland was felt to presuppose a measure of common values and traditions among the population or at any rate its 'core' community" (Smith 1991: 11). It is nation that is meant to be under a political community.

\section{b) Promotion of ethnic conflict}

Constant repetition of differences in culture, tradition and looking at certain historical events amongst ethnicities in Bosnia and Herzegovina by the history textbooks is promoting collective identity and presenting 'the other' as an enemy. Besides promoting a certain belief system and set of values it is raising some emotions amongst people by means of myths and facts that are historically not important. One example of that can be found in a Croatian curriculum history textbook for the 9th grade where it is stated that Croats greeted German soldiers with flowers as they marched in Zagreb (the Croatian capital). Since the Croatian army (Ustashe) in the Second World War has allied with Germans they are clearly presented as enemies. Hobsbawm argues that myth and invention are essential to the politics of identity by which groups of people today define themselves by ethnicity, religion or the past or the present borders of states, try to find some certainty in an uncertain and shaking world (Hobsbawm 1997). Presenting 'the other' as enemy is can be seen in a statement from the Serb history textbook where it is claimed that most Bosnian Muslims have joined the Ustashe (the Croatian army during the WWII) as Bosnia belonged to the Croatian Independent State and have together with Croats organised massacres of Serbs during WWII in Bosnia.

While conducting this research I have seen that the issue in Bosnian education in terms of religious education or secular education was never really solved. Since the Ottoman Empire onwards we had schools that were based on religious belonging and which were only for members of one ethnic group. The Austro-Hungarian Empire tried to establish secular schools in Bosnia, 
but people still attended religious schools in most cases. It can be assumed that the secular schools were too expensive. So the issue of ethnicity and religion has stayed in Bosnia since then. I have also noted that while talking to the teachers and school director they were open and discussed the topic without any breaks, but when it comes to following the curriculum they do not question it. It could be argued that this is the result of political pressure and that they do not want to make any waves, but still, they see what the problem is and where it is going.

What could actually be changed in history teaching in Bosnia? Several scholars, such as Edin Radušić have proposed the 'multi perspective approach', which would allow children to hear different sides of stories about the same historical events (Radusic 2009: 7). It would help to develop a student's critical thinking and save the student from exclusive truths (Radusic 2009: 7). What still needs to be investigated is the reaction of parents to it.

\section{References}

Anderson, David (1995) The Collapse of Yugoslavia: Background and Summary, Foreign Affairs Defence and Trade Group, Department of the Parliamentary Library.

Apple, W. Michael (1993) The Politics of Official Knowledge: Does a National Curriculum Make Sense? Teachers College Record. Volume 95 (2), pp. 222-241.

Apple, W. Michael (2001) Away with all the teachers: the cultural politics of home schooling, available at: http://nepc.colorado.edu/files/Apple.Away_.pdf

Bozic, Gordana (2006) Reeducating the Hearts of Bosnian Students: An Essay on Some Aspects of Education in Bosnia and Herzegovina, East European Politics \& Societies, May 2006(20) no. 2, 319-342.

Bryman, Alan (2004), Social Research Methods, Oxford University Press Inc. New York.

Cole, A. E. and Barsalou, J. (2006) Unite or Divide: The Challenges of Teaching History in Societies Emerging from Violent Conflict, Special report (United States Institute for Peace), available at: http://www.usip.org/sites/default/files/resources/sr163.pdf

Vladimir, Turjačanin; Kolenović-Đapo, Jadranka; Čehajić-Clancy, Sabina; Poljac, Ervin; Kordić, Milenko; Alić, Meliha; Inić, Branka; Radić, Nadežda UNICEF (2009) Divided schools in Bosnia and Herzegovina, available at: http://www.unicef.org/bih/Divided_schools_in_BHWEB_1.pdf 
Durrani, Naureen and Dunne, Máiréad (2010) Curriculum and national identity: exploring the links between religion and nation in Pakistan. Journal of Curriculum Studies, 42(2), 215-240.

Dženana Husremović; Powell, Steve; Šišić, Ajla and Dolić, Aida (2007) [Education in Bosnia and Herzegovina: What do we teach our children? Analysis of national group of school subjects textbooks]. Available at: http://www.erisee.org/downloads/2013/2/bh/Analysis\%20of\%20teachin g\%20books\%20for\%20national\%20subjects\%202007\%20BH.pdf (In Bosnian).

Gellner, Ernest (2009) Nations and Nationalism. Cornell University Press.

Hobsbawm, Eric (1989) Age of Empire. Vintage Books.

Hobsbawm, Eric (1997) On History [Kindle version]. New Press.

Karčić, Harun (2012) From Mekteb-I-Nuwwab to the Faculty of Islamic Studies: A Short History of Bosnia's Leading Islamic Educational Institution. Occasional Papers on Religion in Eastern Europe, 31(1), 4.

Kolouh-Westin, Lidija (2004) Education and democracy in Bosnia and Herzegovina. International Journal of Educational Development, 24, 495-509.

Wolff, Laurence and Breit, Elizabeth (2013) Education in Israel: The Challenges Ahead. The Gildenhorn Institute for Israel Studies.

Malcolm, Noel (1994) Bosnia: A Short History. New York: New York University Press.

Michaels, I. Deborah and Stevick, E. Doyle (2009) Europeanization in the 'other' Europe: writing the nation into 'Europe' education in Slovakia and Estonia. Journal of Curriculum Studies, 200(41: 2), 225-245.

Perry, Valery (2003) Reading, writing and reconciliation: Educational reform in Bosnia and Herzegovina. Working Paper No. 18. Flensburg: European Centre for Minority Issues.

Rabić, Nedim (2013) Manichaeism And The Bosnian Church. Sixth Biennial Convention. Bosniak Institute, Sarajevo, Bosnia-Herzergovina, September 26, 2013.

Radusic, Edin (2009) History Curricula Analysis: A part of the Bridging Histories in Bosnia-Herzegovina project. EUROCLIO (European Association of History Educators. 
Safia, Swimelar (2013) Education in Post-war Bosnia: The Nexus of Societal Security, Identity and Nationalism. Ethnopolitics: Formerly Global Review of Ethnopolitics, 12(2), 161-182.

Salomon, Gavriel (2004) A Narrative-Based View of Coexistence Education. Journal of Social Issues, 60(2), 273-287.

Shany, Payes (2013) Separate education and hegemonic domination: civil society challenges in the Arab-Jewish city of Jaffa. Intercultural Education, 24:6, 544-558.

Sidanius, Jim and Petrocik, John R. (2000) Ethnicity and National Identity: A Comparison of Three Perspectives. Paper Presented at the conference ReThinking Democracy in the New Millennium. Houston, Texas. Available at: http://www.uh.edu/democracy/sidaniust.pdf

Smith, D. Anthony (1991) National Identity. Penguin Books.

Torsti, Pilvi (2009) Segregated education and texts: a challenge to peace in Bosnia and Herzegovina. International Journal on World Peace, 26(2).

UNICEF Inoccenti Research Centre (2000) Two Faces of Education in Ethnic Conflict: Towards a Peace building Education for Children. Available at: https://www.unicef-irc.org/publications/pdf/insight4.pdf

Varshney, Ashoutosh (2009) Ethnicity and Ethnic Conflict. In Boix, Car and Stokes, Susan C. (eds.) The Oxford Handbook of Comparative Politics, pp 274-294.

Zhang, Y. and Wildemuth, B. M. (2009) Qualitative analysis of content. In B. Wildemuth (ed.) Applications of social research methods to questions in information and library science. Westport, CT: Libraries Unlimited, pp. 308-319. 